\title{
Mapping the human record in the British early Palaeolithic: evidence from the Solent River system
}

Article

Accepted Version

Ashton, N. and Hosfield, R. (2010) Mapping the human record in the British early Palaeolithic: evidence from the Solent River system. Journal of Quaternary Science, 25 (5). pp. 737-753. ISSN 0267-8179 doi: https://doi.org/10.1002/jqs.1350 Available at https://centaur.reading.ac.uk/16456/

It is advisable to refer to the publisher's version if you intend to cite from the work. See Guidance on citing.

To link to this article DOI: http://dx.doi.org/10.1002/jqs.1350

Publisher: Wiley

All outputs in CentAUR are protected by Intellectual Property Rights law, including copyright law. Copyright and IPR is retained by the creators or other copyright holders. Terms and conditions for use of this material are defined in the End User Agreement.

www.reading.ac.uk/centaur

\section{CentAUR}


Central Archive at the University of Reading

Reading's research outputs online 


\section{Author's Original Manuscript - Postprint}

This is an Author's Accepted Manuscript (text and tables only) of an article published as: Ashton, N. \& Hosfield, R.T. 2010. Mapping the human record in the British early Palaeolithic: evidence from the Solent River system. Journal of Quaternary Science 25(5): 737-753. 


\title{
Mapping the human record in the British early Palaeolithic: evidence from the Solent River system
}

\author{
Nick Ashton ${ }^{1}$ and Rob Hosfield ${ }^{2}$
}

${ }^{1}$ Department of Prehistory and Europe, British Museum, Franks House, 56 Orsman Road, London N1 5QJ, UK
${ }^{2}$ Department of Archaeology, University of Reading, Whiteknights Box 226, Reading, RG6 6AB, UK

\begin{abstract}
The lithic record from the Solent River and its tributaries is re-examined in the light of recent interpretations about the changing demography of Britain during the Lower and early Middle Palaeolithic. Existing models of the terrace stratigraphies in each of the tributary areas are reviewed and the corresponding archaeological record (specifically handaxes) for each terrace is assessed to provide models for the relative changes in human occupation through time. The Bournemouth area is studied in detail to examine the effects of quarrying and urbanisation on collection history and on the biases it introduces to the record. In addition, the effects of reworking of artefacts from higher into lower terraces are assessed, and shown to be a significant problem. Although there is very little absolute dating available for the Solent area, a cautious interpretation of the results from these analyses would suggest a preMIS 12 date for the first appearance of humans, a peak in population between MIS 12 and 10, and a decline in population during MIS 9 and 8. Due to poor contextual data and small sample sizes, it is not clear when Levallois technology was introduced. This record is compared and contrasted to that from the Thames Valley. It is suggested that changes in the palaeogeography of Britain, in particular land connections to the continent, might have contributed to differences in the archaeological records from the Solent and Thames regions.
\end{abstract}

Keywords: Solent River, Palaeolithic, demography, terrace stratigraphy, handaxes, Levallois

\section{Introduction}

One of the main thrusts of recent research in northern Europe has been the mapping of human presence and absence during the Pleistocene and how this has been affected by climate, environment and, in the case of Britain, by recurrent changes in status from peninsular to island (e.g. Gamble, 1987, 1992; Roebroeks et al., 1992; White and Schreve, 2000; Ashton and Lewis, 2002). Britain has one of the best records against which to test models of human presence together with changes in population, settlement and technology through time. Although the record from primary context sites has often provided the fine-grained detail of human behaviour and habitat (Roberts and Parfitt, 1999; Ashton et al., 2006), the secondary context sites from the fluvial archives also provide a valuable coarse-grained record of shifts through time (Bridgland, 1994; Ashton and Lewis, 2002). These archives consist of stone artefacts in well mapped terrace sequences, which can be used to investigate the first appearance of humans and the introduction of new technologies (Bridgland, 2001; Westaway et al., 2006).

These archives have also been used to examine changes in population and investigate the effects of the insularity and peninsularity of Britain (Ashton and Lewis, 2002). Long-standing models of the formation of the Strait of Dover have suggested that they were formed at the end of Marine Isotope Stage (MIS) 12 (Smith, 1985; Gibbard, 1995), so that Britain could only have been reached by land during cooler episodes after this point. There has also been 
the recognition of an absence of human populations in Britain from at least MIS 6 through to the end of MIS 4 (Stuart, 1976; Currant, 1986; Wymer, 1988; Currant and Jacobi, 2001; Ashton, 2002). In order to test the interpretations of human absence, Ashton and Lewis (2002) examined the Middle Thames and used artefact densities within the terraces as a proxy for human population. The results suggested that at least in that area, not only were populations very small or absent from MIS 6-4, but also that there was a general decline in population from MIS 11 through to MIS 7. On this basis they suggested that the breach of the Dover Strait might be later in time, possibly at the end of MIS 8 or MIS 6. These conclusions have been partly supported by more recent work using bathymetry of the English Channel and southern North Sea Basin (Gupta et al., 2007; Gibbard, 2007), which has led to the suggestion of a more recent, or possibly a second, breach at the end of MIS 6. A later breach of this type would totally change the dynamics of human population movements into and out of Britain.

The reasons for the apparent drop in population from MIS 6 onwards are now perhaps better understood because of the increasing evidence for the climatic severity of MIS 6 and a second post-MIS 12 breach. However, the suggestion that population declined from MIS 11 through to MIS 7 has received less support (Hosfield, 2005; Scott, 2006; White et al., 2006; $\mathrm{McNabb}$, 2007). A variety of possible reasons for the decline in artefact numbers has been suggested. Ashton and Lewis (2002) suggest that this does reflect population and that one possible reason is the increasing adaptation of Neanderthal populations to open steppe environments, which were less prevalent in Britain than eastern Europe. Hosfield (2005) and McNabb (2007) suggest that the pattern of artefact decline is not reflected in the Solent area and that the effects of collecting history play a role. Hosfield further suggests that regional differences in the archaeology might be a factor. In contrast, Scott (2006) and White et al. (2006) argue that changes in technology and landscape use during the early Middle Palaeolithic produces a shift in artefact discard away from raw material sites in the river valleys to a broader range of sites beyond, reducing artefact numbers in the fluvial record.

To test the validity of the data from the Middle Thames and to examine these different hypotheses a fresh look is taken at the archive from the rivers of the Hampshire Basin, including the former Solent River. This archive is also examined to contribute to the wider Palaeolithic debates on the first arrival of humans and the introduction of Levallois technology to Britain.

\section{The Hampshire Basin}

The Hampshire Basin has been recognised as an area rich in Palaeolithic archaeology since the late 1860s. The vast majority of the archaeological record derives from the fluvial sands and gravels of the former Solent River and its principal tributaries, the Rivers Frome, Stour, Avon and Test (Figure 1). The lithic assemblages were predominantly collected in the later part of the $19^{\text {th }}$ and earlier decades of the $20^{\text {th }}$ centuries. Although these collections have been listed in gazetteers and occasionally described in more detailed papers (e.g. Burkitt et al., 1939; Calkin and Green, 1949; Roe, 1968; Wessex Archaeology, 1993; Wymer, 1999), it has only been over the last 10 years that serious attempts have been made to understand better the overall nature and dating of the archaeological record (e.g. Hosfield, 1999, 2001; Bridgland, 2001; Wenban-Smith, 2001; Briant et al., 2006, 2009b; Westaway et al., 2006).

One of the difficulties of understanding the archaeological record has been the differing schemes used to map the terraces in different tributary areas and between the lower and 
higher reaches of individual rivers, but also the occasional lack of agreement over the reinterpretation of these schemes. This has caused confusion and has complicated archaeological interpretation.

A further problem has been the dating of the terraces in different areas. With the paucity of biological remains within the sediments it has been difficult to use biostratigraphy in all but a few cases. Where organic remains are preserved, such as at Pennington Marshes and Stone Point at Lepe, they have always been found in low-lying terraces, attributed to MIS 7 or later. More recently Optically Stimulated Luminescence (OSL) work has begun to help with the dating of some of the lower terraces, although there is less certainty about the reliability of the dating of higher terraces (Briant et al., 2006, but see Briant et al., 2009c; Briant and Schwenninger, 2009).

There has also been an attempt to use archaeology to date the different terraces (Westaway et $a l ., 2006)$, whereby the first appearance of artefacts, the introduction of Levallois technology and the arrival of bout-coupé handaxes have been argued to be tie-points, dated to MIS 15, MIS 9/8 and MIS 3 respectively. However, there are two serious problems with the method. The date they use for the first appearance of humans in Britain is based on their reinterpretation of the assemblage at Pakefield (Suffolk) to MIS 15, despite the widely accepted age of MIS 17 or late 19 for this site (Parfitt et al., 2005). There is a further problem in using the introduction of Levallois to date terraces. This is in part due to the low number of Levallois artefacts from the Solent, but also due to a lack of scrutiny of the published identifications (Roe, 1968) or of their actual contexts. Specific criticisms of their approach are given in the relevant area studies below. For these reasons the dating put forward by Westaway et al. (2006) is not used in this paper.

With the recognition of many of the problems with the Solent data, Hosfield (1999) undertook a thorough review of the archaeological record with the use of GIS modelling to understand the distribution of the archaeology, taking into account the varying processes of archaeological discovery, together with the taphonomic problems of artefact transport and reworking. The results were used to underpin models of human behaviour and landscape use on a local and regional scale.

The current study draws on much of this information together with more recent work, and is primarily aimed at addressing the questions of human arrival, technological change and by using artefact densities identifying possible population changes through time. The relative terrace records in each tributary system are compared, taking into account the effects of taphonomy, variable collecting histories and the different interpretations of the terrace stratigraphy. A local case study, building on earlier work by Hosfield (2005), is presented of the Bournemouth area where the terrace mapping of Allen (1991; Allen and Gibbard, 1993) is in broad agreement with that of Bristow et al. (1991) and where collection history is better understood.

\section{Methods}

The study is based on the listing of sites with artefact numbers published in the Southern Rivers Palaeolithic Project (SRPP; Wessex Archaeology, 1993) with occasional additions found from new studies of collections and archives. Some assemblages have also been examined first-hand, particularly from the Bournemouth area (SI Table 1). The vast majority of assemblages were collected, rather than excavated, during the latter part of the $19^{\text {th }}$ and 
earlier part of the $20^{\text {th }}$ centuries. For this reason nearly all the collections are biased towards handaxes, rather than flakes, with only 67 Levallois artefacts from the entire area. Although the low quantity of Levallois material might be due to biases in collection, in the Thames catchment, which has a similar collecting history, large Levallois assemblages were collected from several major sites. This suggests that the low Levallois counts for the Solent reflect a genuine dearth of Levallois sites in this region. Whether this is a reflection of low population, or that other technologies were used during MIS 8 and MIS 7 in the Solent area, is not clear. Due to these difficulties, handaxes alone are used in the artefact density analysis to study potential population changes. It is assumed that handaxes no longer form a major component of the human technology from MIS 7 onwards, and therefore only terraces likely to be MIS 8 or older are used.

The survival of terrace gravels differs considerably both within and between areas. To factor out biases in survival, each terrace area has been quantified and handaxe densities based on area have been calculated (Table 1). One problem with this method is that the density is not based on volume. Unfortunately the sparse distribution of boreholes on which the terrace mapping is based, and the wide variation in depth of the gravel as shown by the borehole records (Bristow et al., 1991; SI Table 2), does not allow a realistic estimation of volume. It should also be noted that some of these boreholes did not reach the base of the gravel or recorded truncated terrace sequences. For the purposes of this paper it is assumed that terrace thickness is broadly similar, supported to some extent by the mean values (SI Table 2).

The condition of the artefacts provides important clues to their taphonomic history and the type of sediment in which they were found. The main attributes include rolling, abrasion, staining and patination (cf. Harding et al., 1987; Ashton, 1998; Hosfield and Chambers, 2005; Chambers, 2005). Artefacts from the terrace gravels tend to be stained with varying degrees of abrasion and rolling. Their condition might be due to several factors, but reworking from higher terrace sediments, or being carried downstream as part of the bed-load are the most likely causes. In contrast, some artefacts are in fresh condition, usually with a

white patination. The latter is often formed in sub-aerial conditions and associated with acidic soils (Stapert, 1976). The significance of these distinctions in artefact condition is underlined by clear technological differences in the Solent artefacts, with handaxes being predominantly rolled and stained, but Levallois artefacts being usually patinated and fresh. The different origin of the fresh material is also supported by the observations of Burkitt et al. (1939) at Warsash, who described fresh, patinated material as coming from fine-grained sediment overlying terrace gravels.

One further problem with the Solent area is the dominance of single assemblages or 'supersites' in some tributary valleys. Biases in the record may have been created by the ease of collecting from large gravel quarries, which would have been compounded by other collectors being attracted to the pits. To help address this issue, more weight is given to patterns that emerge from a range of different sites with good samples of handaxes (e.g. > 50), rather than reliance on large single sites (Table 4).

\section{River Frome}

The River Frome flows from above Dorchester into Poole harbour, and is interpreted as following the course of the Upper Solent River (Figure 1). There have been various complex interpretations of the terrace stratigraphy of the Frome between Dorchester and Wareham. They largely divide into the schemes developed by Mathers (1982b) and Allen and Gibbard 
(1993) who identified nine main terraces with relatively steep gradients, and the scheme based on Green $(1946,1947)$, but developed by Westaway et al. (2006) with subdivision of some of these terraces and with the assignment of shallower gradients. The difference between the interpretations of the gradients has implications for how these terraces correlate with those in the Bournemouth area and also for the timing of the breaching of the Chalk ridge between Purbeck and the Needles. The breaching led to the diversion of the Upper Solent into a new route to the west of the Isle of Wight. The scheme used here is that of Allen and Gibbard (1993).

The age of the terraces is unknown. Due to the large number of handaxes and the absence of Levallois in the West Knighton Gravel (Table 1), Westaway et al. (2006) attributed the gravel to MIS 10. However this interpretation is seriously challenged by the abundance of handaxes in various terraces elsewhere in the Solent and the paucity of Levallois in general. Therefore their interpretation of the dating is not followed here.

\section{River Stour and Bournemouth area}

There appears to be broader agreement in the mapping of the terraces in the Bournemouth area. Bristow et al. (1991) mapped 13 terraces (T1-T13), which broadly correspond to the named terraces of Allen and Gibbard (1993). Terrace 13 was split by them into the Tiptoe and Sway gravels and described by Westaway et al. (2006) as Terraces 13a and 13b. The mapping used here is that of Allen and Gibbard (1993), although (after Briant et al., 2006) using the western Solent terminology (e.g. Taddiford Farm Gravel for Ensbury Park Gravel; Figure 2a). Some terraces in this area are attributable to the Solent rather than the Stour (e.g. the Old Milton Gravel to the south of the Setley Plain Gravel in Bournemouth). However, the Solent terraces within the Bournemouth area have been included within the Bournemouth analysis as they have been mapped as equivalent aggradational units to those of the Stour.

As with the Frome there are few constraints on the age of the terraces. Westaway et al. (2006) argued that Levallois was introduced during the formation of the Taddiford Farm Gravel and therefore they dated this terrace to MIS 9-8. However, Levallois is also recorded from areas mapped as Old Milton and Setley Plain gravels, so any dating of this type requires more detailed scrutiny (Table 1).

\section{River Avon}

There is less agreement about the terrace stratigraphy along the Avon. The river naturally divides into the Upper Avon (upstream of Downton, near Salisbury), and the Lower Avon. In the Upper Avon terraces are mapped as either Higher or Lower. The vast majority of sites and artefacts come from the Higher Terrace. Unfortunately it is difficult to relate these terraces to the Lower Avon, where a more complex sequence has been identified (Table 1).

The most widely used scheme for the Lower Avon is that of Kubala (1980) and Clarke (1981), who recognised ten terrace gravels (T1-T10) and five older river gravels ('Higher Terrace Gravels') on the New Forest plateau (Figure 2c). This scheme was expanded by Bristow et al. (1991) who subdivided the ten terrace gravels into 14. Allen and Gibbard (1993) largely followed this scheme, but also considered in more detail how these terraces correlate with the main Solent terraces in the lower reaches of the Avon. A different scheme (C8-C16) was produced by Westaway et al. (2006) with shallower gradients, but it is not 
clear what archaeology occurs in each terrace. Therefore, the scheme followed here is that of Kubala (1980) and Clarke (1981), which is also the scheme used in the SRPP (Figure 2c).

There are few constraints on the dating of the terraces, other than a ${ }^{14} \mathrm{C}$ date of $41 \mathrm{ka}$ on peat (Barber and Brown, 1987) at Ibsley beneath Terrace 3 of Kubala (1980). Westaway et al. (2006) again used the absence of Levallois in handaxe-rich gravels for dating, even though they listed only one Levallois artefact from the whole of the Avon catchment (Table 1). This piece actually comes from one of the two principal sites, St Catherine's Hill, which is mapped as Terrace 8 (Kubala, 1980) or Setley Plain Gravel (Allen and Gibbard, 1993). The latter regarded this deposit as upstream of the Stour-Avon confluence and part of the Stour system. This interpretation is followed here.

\section{Western Solent in the New Forest area}

The terraces of the Solent in the New Forest area were first mapped in detail by Mathers (1982a), who recognised 10 numbered terraces. The area was remapped by Allen and Gibbard (1993) producing a new scheme with 14 named terraces (Figure 2b). The latter's different correlations between gravels in the east and west of the area created steeper gradients than those of Mathers (1982a) for the terrace units. Finally, Westaway et al. (2006) reverted to the shallower terrace gradients of Mathers, but also added additional terraces to the scheme with new names. However due to the paucity and poor provenancing of the artefacts the different mapping schemes have little impact on the archaeological interpretation. Therefore the scheme of Allen and Gibbard (1993) is used in this paper (Figure 2b).

There are better dating constraints in this area than other parts of the Solent system. Organic beds attributed to MIS 5e have been found within the Pennington Gravel of Allen and Gibbard (1993). At Stone Point organic deposits have also been recorded, but occurring within the Lepe Gravel of Allen and Gibbard (1993). Although these organic beds were originally attributed to MIS 5e (West and Sparks, 1960), it has been suggested that due to their higher altitude (c. 3-4m higher) they might date to MIS 7 (Allen et al., 1996). Westaway et al. (2006) renamed both the Pennington Gravel and the Lepe Gravel as the St Leonard's Farm Gravel and attribute both the organic deposits to different stages of MIS 5e. This interpretation has been supported by OSL dates on the gravels (Briant et al., 2006, 2009a).

Briant et al. (2006) undertook further OSL dating at other sites in the western Solent, but the only consistent dates were from the Stanswood Bay Gravel, which they attributed to MIS 8. Dates on the attitudinally higher Tom's Down Gravel and Old Milton Gravel showed considerable variation, and were initially not regarded as reliable by the authors. However, recently attribution to MIS 8-9 and MIS 9-11 respectively have been suggested for these two gravels (Briant and Schwenninger, 2009; Briant et al., 2009c).

\section{Test Valley}

The most detailed work in the Test Valley was undertaken by Edwards and Freshney (1987) who mapped 11 numbered terraces (Figure 2d). This scheme was modified by Westaway et al. (2006) giving the terraces new names, the most significant adjustment being to the terraces at Warsash. These had previously been mapped as predominantly Terrace 3 , but also with areas of Terrace 2. Westaway et al. argued that Terrace 3 equated upstream to Terrace 4, based on terrace projections. Unfortunately the projection they showed in their Figure 17 put 
the terrace deposits at Warsash some $10 \mathrm{~m}$ too high (i.e. at c. $25 \mathrm{~m}$ OD). Ground surface heights in this area only attain $15 \mathrm{~m}$ OD, which therefore casts serious doubt on their reinterpretation. As a result, the mapping of Edwards and Freshney (1987), as used in SRPP, is also adopted for this paper (Figure 2d).

As with most other areas, there are few dating constraints on the terraces. Westaway et al. (2006) used Levallois material from Warsash as a means of dating. It is clear from the description of Burkitt et al. (1939) and the condition of the artefacts that the Levallois material comes from above the terrace deposits. They therefore suggested that Terrace 4 (mapped by Edwards and Freshney as Terrace 3 around Warsash) dated to MIS 10. Unfortunately there is currently no other dating evidence.

\section{The early Palaeolithic record of the Solent}

The artefact record and handaxe density figures for the different tributary and main Solent River channel areas are shown in Table 1 and a tentative correlation between the areas is suggested in Table 2. This is partly based on Allen and Gibbard's (1993) correlation between the Avon Terrace 6 (their High Cliff Gravel) and the Taddiford Farm Gravel. Further correlations can be suggested between the western Solent and the Test by comparison of terrace heights immediately upstream of their confluence. The Test terraces near Warsash are only $5 \mathrm{~km}$ to the east of the western Solent terraces near Fawley, on opposite sides of Southampton Water (Figure 2). Given the similar topography and terrace gradients, both areas should have comparable terrace heights. This suggests that the Stanswood Bay and Tom's Down gravels of the western Solent are equivalent to Terraces 2 and 3 of the Test respectively. Logically it would be thought that the Old Milton Gravel (being the next terrace up) would be equivalent to Terrace 4, but the latter has heights that equate better with the Mount Pleasant Gravel. Although the dating of these terraces is largely unknown, there are reliable OSL dates on the Stanswood Bay Gravel, suggesting attribution to MIS 8. The suggested dating by Westaway et al. (2006) is given for comparison in SI Table 3. The results of the current artefact analysis are presented below.

\section{Earliest appearance}

The first arrival of humans in the Solent Basin can be assessed from the earliest artefact records from the different study areas. In all areas small numbers of artefacts have been found one or usually two terraces higher than those with peak artefact densities (Tables 1 and 2). However, in many cases it is not known whether the artefacts were surface finds or found within the terrace gravels. For the River Frome, a single handaxe was found in an area mapped as Tonnerspuddle Heath Gravel and possibly one from the Higher Hyde Heath Gravel, but in neither case can the artefacts be securely attributed to the terrace gravels.

In the Bournemouth area three handaxes were found associated with the Tiptoe Gravel, with one marked as 'base of gravel', and another marked as 'Wills Pit'. A strong contender for early archaeology is the under-studied group of 12 handaxes from Foxholes, an area of $19^{\text {th }}$ and early $20^{\text {th }}$ century pits dug into the Sway Gravel.

Six handaxes have been found in areas mapped as Terrace 8 of the Avon. Five of these pieces are described by Crawford et al. (1922) as coming from gravel pits at 200ft at Rockford Common, Crow Hill and Hightown Hill, all near Ringwood. At least one of the artefacts from Rockford Common is described as being recovered in loose, uncemented gravel, 6-10ft below 
the surface. They are all rolled and stained, and there seems little doubt that some, if not all, of these handaxes come from within the terrace gravel.

The western Solent has produced handaxes on Setley Plain to the south of Brockenhurst, from pits which cut into sediments mapped as Setley Plain Gravel. One of these is illustrated in Crawford et al. (1922) and described as coming from terrace gravels. These authors suggest that handaxes were frequently found in these gravels, but only one piece survives. Further handaxes were noted by these authors to be found in pits $1 \mathrm{~km}$ to the south near Bottramsley in deposits again mapped as Setley Plain Gravel. Bury (1923) described and illustrated three further implements (and suggests the existence of others) from the Setley Plain locality, recovered from a pit at $c$. 8-10ft below the surface (itself estimated at $c$. 140ft OD). It again seems reasonable to argue that these handaxes came from the body of the gravel, and it is notable that Bury highlights the absence of artefacts from between 150-300ft OD (although he also mentions the paucity of open pits at these higher elevations).

Finally, in the Test Valley, although the highest density of archaeology occurs in Terrace 4, there are instances of handaxes found in deposits as high as Terrace 11. There are two handaxes listed for Terrace 11, but there is no detailed location or contextual information. The same applies to one handaxe associated with Terrace 10. A handaxe associated with Terrace 9 is listed as coming from the White Rail Pit on Netley Common. This might be a candidate for archaeology within terrace gravel. Eleven handaxes are listed as coming from Midanbury Hill in Southampton, which is mapped as Terrace 8, but with no details on context. The same applies to the five handaxes from Stanbridge (near Romsey) associated with Terrace 7. The context is far more certain for the important assemblages from Pauncefoot Hill Gravel Pit and the Ridge Gravel Pit near Romsey Extra, which have been dug into the Terrace 6 gravels. The Ridge Gravel Pit has produced about 120 handaxes, all collected since the 1990s. Therefore, other than a possible handaxe in Terrace 9, the earliest certain occurrence of handaxes in fluvial gravels is in Terrace 6.

The first appearance data therefore suggests that handaxes probably first occurred in the Sway Gravel in the Bournemouth area, Terrace 8 of the Avon, the Setley Plain Gravel of the western Solent and Terrace 6 of the Test. If the correlations in Table 2 are broadly correct, then the earliest handaxes occurred in sediments at least as old as MIS 13

\section{Levallois}

The occurrence of Levallois artefacts can potentially be studied from the Solent Basin to ascertain the arrival of this technology in the region. By contrast it was used by Westaway et al. (2006) as a tie-point to help date the terraces in the basin. As they correctly state, the first evidence of 'proto-Levallois' in Britain seems to date towards the end of MIS 9 or early MIS 8 at Botany Pit, Purfleet (White and Ashton, 2003). It occurs more routinely in the Thames valley during late MIS 8 and MIS 7 at sites such as Ebbsfleet, the Lion Pit Tramway Cutting (Thurrock) and probably Crayford as part of the deposits ascribed to the Taplow-Mucking Formation (Bridgland, 1994; White et al., 2006). It also seems to occur widely in fresh condition on the surface of the Lynch Hill Gravel in west London at sites such as Creffield Road (Acton) and in the West Drayton and Yiewsley areas (Ashton et al., 2003; White et al., 2006). There are no clear records of it occurring within the Lynch Hill Gravel, from which large quantities of rolled handaxes have been recovered.

Elsewhere in Britain the occurrence of Levallois is rare and usually poorly dated, with the exception of Pontnewydd Cave (north Wales), where it occurs with handaxes and probably 
dates to a cooler phase in MIS 7 (Green, 1984; Aldhouse-Green, 1995). In contrast there are sites in south-west England (Harnham and Broom) that have yielded assemblages containing handaxes, apparently without Levallois, which seem to be comparatively late in date. Harnham has recently been dated by biostratigraphy and amino acids to late MIS 8/early MIS 7 and has no evidence of Levallois (Whittaker et al., 2004). Meanwhile the sediments at Broom have been dated by OSL, suggesting occupation during MIS 9 and MIS 8 (Toms et al., 2005; Hosfield and Chambers, in press). Although three Levallois artefacts are noted by Roe (1968) and repeated in later publications (e.g. Wessex Archaeology, 1993), recent studies of the principal collections at the British Museum (Marshall, 2001), Exeter's Royal Albert Memorial Museum and Art Gallery, and Dorset County Museum (Hosfield and Chambers, in press) have failed to identify them.

In the Solent area 71 Levallois artefacts are recorded, but some of these have not been examined since Roe (1968). In the current study 45 have been examined, but at least four of these are not Levallois, reducing the total figure to no more than 67. In distribution, none are recorded from the Frome and Avon valleys, and only two from Barton Cliff in the western Solent, with 29 and 36 Levallois artefacts associated with terraces from the Bournemouth area and Test Valley respectively.

For the Bournemouth area, 12 of the 29 pieces can be confirmed as Levallois, while it has not been possible to examine the remaining 17 pieces. If these have been correctly identified, then the vast majority (21) are associated with the Taddiford Farm Gravel, six with other terraces, and two with non-terrace areas (Table 3). Although a potentially early date for Levallois might be suggested by one possible core apparently associated with the Setley Plain Gravel, there are no contextual details (Kevin Dearling, pers. comm.).

Of the 12 Levallois pieces examined, only two have a recorded context. A slightly abraded Levallois flake comes from the Corfe Mullen area, but the context, other than 'Stour Gravels', is unclear. A further rolled Levallo is flake comes from 'near [the] top' of the Brixey and Goods Pit in East Howe (mapped as Milford-on-Sea Gravel) and a further fresh Levallois flake was recovered 'from loam' in Huntley Road, Bournemouth (mapped as Old Milton Gravel). A further six Levallois pieces are also in fresh or slightly abraded condition, and rather different to the condition of the associated handaxes. This might suggest that these pieces come from sediments overlying the terrace gravels. However, there are also four examples which are in a rolled condition, of which three are associated with the Taddiford Farm Gravel and one with the Milford-on-Sea Gravel. Their condition might suggest that Levallois technology is introduced during the aggradation of the Taddiford Farm Gravel.

Of the 36 Levallois pieces recorded from the Test Valley, 24 come from the pits at Warsash. Although in SRPP 13 of these are attributed to the Fleet End Pits on Terrace 3, only one of these has been located in the current study. The remainder might be included in the 19 Levallois pieces from the general Warsash area which covers both Terraces 2 and 3 . The Warsash artefacts were described by Burkitt et al. (1939) and it is clear from their description of Park's Pit that at least some were found from just below a blue clay and were not part of, but located above, the terrace gravels. Unfortunately Park's Pit has not been relocated since Burkitt et al. (1939). The context of the Levallois artefacts is further supported by their condition. Together they form a coherent group being slightly abraded with creamy patination, and are very different in condition to the rolled, iron-stained handaxes from this area. 
There are a further 12 Levallois artefacts from elsewhere in the Test Valley. Of the five (out of six) examined from Belbin's and Chivers pits, north of Romsey, all but one are in a slightly abraded, patinated condition, in marked contrast to the handaxe material from the same sites. Again, they probably come from sediments overlying the Terrace 4 gravels. Other artefacts associated with Terrace 4 gravels (at Ashfield, Highfield and Dunbridge) have not been located. Of the remaining two artefacts, one is a Levallois point in fresh condition from Lee-on-Solent, an area mapped as Terrace 2, while the other is a rolled, stained flake from Colden Common, which is mapped as Terrace 3.

In summary, there are no clearly documented examples of Levallois material actually being found within terrace gravels. However, if the rolled and stained condition of artefacts is used as a criteria for placing them within terrace gravels, then it might suggest that Levallois was present within the Taddiford Farm Gravel in the Bournemouth area and, with even less certainty, within Terraces 3 and 4 in the Test Valley. Given the uncertainty of context, the tiny database and the likely interpretation that the majority of Levallois artefacts come from overlying sediments, it is clear that the presence of Levallois in the Solent area cannot be used reliably as a means of dating the terraces, particularly in the south-west region where the timing of its introduction is uncertain.

\section{Patterns of change}

The distribution of the handaxes in the different terraces can potentially be used to study changes in human activity over time. Unfortunately for some tributary areas the handaxe counts are too small, or are too dominated by single assemblages to provide meaningful results. Major sites dominate the otherwise very low artefact counts from the River Frome and River Avon. For the Frome virtually all the artefacts come from the Moreton Gravel pits, mapped as West Knighton Gravel. In the case of the Avon, the record is dominated by the prolific site of Wood Green, mapped as Terrace 7. This is mirrored by the results from the Upper Avon, in particular from Salisbury, where the vast majority of artefacts come from the Higher Terrace.

For the western Solent's 255 handaxes, 200 are marked as coming from the beach and cliffs at Barton-on-Sea (Old Milton Gravel). However, Evans $(1897,637)$ implied that some of these artefacts may also have come from coastal exposures between Chewton Bunny and Milford-on-Sea, an area that also covers Taddiford Farm, Stanswood Bay and Milford-on-Sea gravels. Inland there has been comparatively little quarrying and little urban development, which probably explains the paucity of artefacts in these areas. If the Barton-on-Sea assemblage is removed from the analysis due to the uncertain provenance, the number of artefacts is too low to provide significant results.

Although there are difficulties with the records from the Frome, Avon and western Solent due to provenance and the domination of single sites, it is still notable that the marked peaks all occur within the earlier, rather than later terraces. For the Frome the peak is in the West Knighton Gravel, for the Avon Terrace 7 and the Higher Terrace upstream, and for the western Solent probably the Old Milton Gravel. If the correlations in Table 2 are correct, then peak densities for the Avon and western Solent are at least two terraces higher than the Stanswood Bay Gravel and therefore a conservative estimate would place these peaks in MIS 10 or older.

The Test Valley and the Bournemouth area have produced much larger artefact assemblages, and although there are some very large sites, they come from a range of different terraces, 
and are complimented by significant quantities of artefacts from other locations. The history of quarrying and urban development has also meant that there have been opportunities for collection from a range of different terraces. The artefact density results for the Bournemouth area appear to show a clear pattern with a peak density in the Setley Plain Gravel and a high density in the Taddiford Farm Gravel. However, one anomaly is the low artefact density in the Old Milton Gravel. This is particularly curious given the apparent abundance of handaxes in this same gravel on the other side of Christchurch Bay in the western Solent area.

A further problem with the pattern from the Bournemouth area is the peak density within the Setley Plain Gravel, which is caused by the prolific sites at Corfe Mullen. If these sites are removed from the analysis, then the artefact density for the Setley Plain Gravel is reduced to c. 17 handaxes $/ \mathrm{km}^{2}$, making it a far less significant peak. If the large assemblage from King's Park is also removed, this reduces the artefact density from the Taddiford Farm Gravel to c. 40 handaxes $/ \mathrm{km}^{2}$. Despite the data adjustments these two terraces still retain high peaks however. If the correlations in Table 2 are correct, then the Taddiford Farm Gravel probably dates to MIS 9 or 10, and the Setley Plain Gravel to MIS 12 or earlier.

The Test Valley data reveals a clear peak in Terrace 4, and a relatively high density in Terrace 2. This is partly accounted for by the prolific assemblages from Dunbridge and by those from Hill Head respectively. But even if these assemblages are removed from the analysis, Terrace 4 still has higher artefact densities than the other terraces with over 40 handaxes $/ \mathrm{km}^{2}$. The correlation in Table 2 would suggest that the peak in artefact density is attributable to MIS 12 or earlier.

There is a general pattern in all the study areas of artefact density peaks occurring in higher rather than lower terraces. A conservative interpretation of the evidence, based on OSL dates and relative terrace position, would suggest that most peak densities occur in sediments dated to MIS 10 or earlier.

\section{'Super-sites'}

'Super-sites' are defined as assemblages that contribute more than $10 \%$ of the total handaxes from an individual study area. The dominance of such sites potentially bias the archaeological record by reflecting collection opportunities rather than patterns of artefact distribution. The amount of bias that the 'super-sites' are possibly creating can be shown through the percentage of handaxes that each site contributes to the individual terrace, and to the area as a whole (Table 4). This problem has been partially dealt with by treating with caution some of the data presented from the Frome, Avon and western Solent. It has also been shown, how Corfe Mullen and King's Park dominate the Bournemouth area, and Dunbridge the Test Valley, although removal of these sites from the analysis still leaves the peak densities in those same terraces. A more detailed analysis is shown in SI Table 4.

It is also worth investigating the nature of the 'supersites' and where they occur in the landscape, which is often just downstream of the Chalk/Tertiary bedrock boundaries (Figure 1; Table 4). The explanation for this phenomenon is in part due to an abundance of fluvial gravels at and below this juncture. The abundance can be explained by the steeper gradients of the rivers through the Chalk, with steeper-sided valleys and with few terrace gravels surviving in these areas. The consequence was the offloading of the gravel once the rivers reached the Tertiary bedrock where there were shallower river gradients. On the Tertiary bedrock the rivers appear to have migrated laterally, which allowed for the preservation of the terrace deposits discussed above (cf. Allen and Gibbard, 1993; Bridgland, 1985). 
The rich gravels in these Chalk/Tertiary boundary areas would have created good raw material sources for early humans, which partly explains the existence of large assemblages in these areas. In addition, the gravels probably contain a large reworked element from earlier terraces in the Downland valleys, as suggested by Hosfield (2001) for the heavily re-worked artefacts in the Dunbridge (River Test) and Wood Green (River Avon) assemblages. Finally, the gravels were a rich resource for modern aggregate companies, who in the late $19^{\text {th }}$ and early $20^{\text {th }}$ centuries exposed these gravels to handaxe hunters and the consequent proliferation of large collections.

The effect of biases in collecting for the Bournemouth area is dealt with in more detail below, and for the Test Valley it does not appear to have a major effect on the figures. However, there are a few observations that can be made for other areas. Other than the Moreton Pits, collecting opportunities in the Frome Valley were extremely limited. For the western Solent, Barton Cliff provided the easiest opportunities being adjacent to the large resort of Bartonon-Sea. Although other collecting opportunities were available, and may have been exploited (Evans, 1897, 637) these were along less accessible, less populated parts of the coast. More can be said about the Avon Valley, where the collections are dominated by Wood Green. In fact this was a comparatively small quarry in Terrace 7, but yielded over 400 handaxes despite much more extensive quarrying into Terraces $3,4,7$ and 8 to the south between Fordingbridge and Ringwood. Study of the history of Wood Green has suggested that the large assemblage from this pit was due to the activities of a local collector, Ernest Westlake, at the end of the $19^{\text {th }}$ century (Hosfield, 1999, 37). The historic mapping for the Avon valley immediately north of Ringwood shows that several sand and gravel pits (around Ibsley, Rockford, and Poulner) were also active at this time. It is clear from Westlake's archive that he was aware of, and probably visited, some of these sites (Hosfield, 1999, 38-39), which suggests that the large assemblage from Wood Green was not simply created by biases in collection.

\section{The Bournemouth study area}

The Bournemouth area is particularly rich in artefacts and has had a long collecting history. It lends itself to further investigation of some of the specific questions that have arisen from the discussions above. These include questions about how the development of gravel extraction and the timing of the urbanisation of Bournemouth have affected access to the different terrace deposits and the consequent collection of Palaeolithic artefacts. Where possible the data has been assessed in a similar way to the information presented in Ashton and Lewis (2002) for ease of comparison, although due to the chronological uncertainties of the Solent terraces, it has been necessary to assume that the durations of the different terraces are equivalent. The Bournemouth data can also be used to investigate the derivation of artefacts from upstream or from higher terrace gravels and the effect that this may have had on artefact densities.

\section{Quarrying and urbanisation}

For the Bournemouth area the collection of Palaeolithic artefacts was at its peak during the 1920s and 1930s, as is evident from the assemblages from King's Park, Corfe Mullen and Moordown (e.g. Bury, 1923, 1933; Green, 1946; Calkin and Green, 1949). Therefore understanding the development of quarrying and urbanisation through this period is essential to understanding the archaeological record. Unfortunately the mapping of quarries in SRPP (Wessex Archaeology, 1993) was selective and does not provide time interval data. Therefore 
gravel and sand quarry locations, extents, and their approximate ages have been digitised from the UK's County Series 1:10,560 mapping ( $1^{\text {st }}$ edition, and $1^{\text {st }}, 2^{\text {nd }}$, and $3^{\text {rd }}$ revisions $)$.

The analysis shows that there was an increase from before 1872 to c. 1900 in the number and average size of active quarries, and in the size of the largest quarries (SI Figure 1; SI Table $5)$. However, small quarries $\left(<1,000 \mathrm{~m}^{2}\right)$ were still present throughout the period. From $\mathrm{c}$. 1910 to 1940 there was a decrease in the number of quarries and a small reduction in the overall area covered by quarrying, but the trend towards larger individual extraction sites continued. The quarries were typically sited on the margins of urban Bournemouth, although smaller quarries in particular did occur within built-up areas.

The mapping also indicates important differences in the exposure of different terrace deposits through quarrying (Figure 3a). The Sway Gravel was the most extensively quarried, with major activity after about 1900. Significant areas of Setley Plain, Taddiford Farm and Stanswood Bay gravels were also quarried after about 1870, 1900 and 1934 respectively. In contrast, any exposures of the Old Milton Gravel were minimal after about 1910. This may help to explain the low numbers of artefacts from this gravel as little was exposed during the peak of collecting in the 1920s and 30s. The working of the Milford-on-Sea Gravel was limited in scale throughout the entire period.

The general trend towards fewer, larger quarries is also shown for the individual terraces, in most cases the size peaking between about 1910 and 1930 (Figure 3b; SI Table 6), which may be important if larger, longer-running quarries were visited more regularly by collectors. Of particular note was the dramatic rise in average quarry size in the Stanswood Bay Gravel during the 1930s, reflecting the presence of a large extraction area south-west of Canford Magna. However, an exception was the Old Milton Gravel where there were no active quarries during the 1920s and only one in the 1930s, during a key period of collection. The data also show that the number of quarries exploiting Setley Plain Gravel increased during the 1920s and 1930s, although the decline in average size during the 1930s might have discouraged collecting from these pits.

The changing urban extents of Bournemouth were also digitised from the 1:10,560 mapping. None of the six terraces were significantly urbanised by the time of the $1^{\text {st }}$ edition mapping and were therefore not exposed on a significant scale prior to the recognition of human prehistory and the significance of Palaeolithic artefacts. Major expansions occurred between all of the mapping editions/revisions with urban areas growing by 308\% (from $c$. 18701890), $162 \%$ and $157 \%$ respectively. Unlike the quarries, urbanisation covers a significant proportion of the terrace deposits, and there are some notable differences between the terraces (Figure 3c). In particular, there was considerably more urbanisation on the Taddiford Farm Gravel and significant development on the Old Milton Gravel, primarily occurring between 1900 and 1930. Again this period covers a key time for collecting.

Inclusion of the quarrying and urban extents data into an artefact density model for these terraces (after Ashton and Lewis, 2002) controls for the impact of differential terrace exposure and collection opportunities upon the artefact density patterns (Figure 4; Table 5). The Taddiford Farm Gravel maintains a rich artefact signal for all three measures, despite the extensive urbanisation over this terrace, while the weaker artefact signals for the Sway, Tiptoe, Old Milton and Stanswood Bay gravels would appear to be genuine, and not the products of limited exposure of those deposits. 
The patterns for the Setley Plain and Milford-on-Sea gravels are more complex. The Setley Plain artefact densities are relatively high and comparable to the Taddiford Farm data when measured against deposit and urbanised deposit areas. However the strength of the signal is greatly reduced by the quarry data, which highlights the proportionally extensive working of this deposit (e.g. at Corfe Mullen) and suggests that the numbers of artefacts from the Setley Plain Gravel are at least in part a product of better collection opportunities. The Milford-onSea artefact record is significantly boosted by the urbanisation data, which highlights the limited exposure of this deposit, while quarrying of this gravel was also small-scale.

Overall the model suggests that the apparent artefact 'spike' in the Taddiford Farm Gravel is a genuine pattern, that the Setley Plain's apparent richness may be somewhat overrepresented, and that the Milford-on-Sea Gravel is potentially richer than it appears. However, these observations also need to be considered against the impact of artefact derivation upon the archaeological record.

\section{The effect of handaxe derivation on the archaeological record}

The secondary context of the archaeology within terrace gravels is a problem when considering them as a reflection of human activity and potentially population. The only certainty is that the artefacts cannot be younger than the gravel in which they are contained. With very few exceptions the artefacts in the Solent catchment as a whole, and specifically within the Bournemouth area, are clearly derived, being both rolled and abraded. The process of derivation is complex, but there are likely to be two major forms. Artefacts could have been transported downstream, making them broadly contemporary with the gravel bed-load. Alternatively, artefacts could have been reworked from higher terrace deposits, making them considerably older than the formation of the gravel in which they were found.

One method of trying to distinguish between the two types of derivation is to analyse the degree of abrasion and rolling within the different terrace units. If reworking from higher terrace units is a significant problem, then it would be expected that the proportion of rolled material would increase in lower terraces. If, on the other hand the material was simply derived from upstream, there should be a similar range of rolled material within each terrace.

For this section a total of 669 handaxes (39\% of the Bournemouth area collections) have been studied, with the degree to which each handaxe has been abraded and rolled noted on a scale of 1 to 4 (as defined in Ashton, 1998). The results for each terrace (Figure 5) suggest that there is an increase in rolling and abrasion of handaxes through time from the Setley Plain Gravel to the Milford-on-Sea Gravel. This supports the idea that a significant number of handaxes were derived from higher terraces into lower terraces.

A different way of assessing the derivation of handaxes is through studying the terrace areas and assessing the likelihood of some gravels being reworked by the river into lower terraces. The gravels in the Bournemouth area are mainly attributable to the Stour, but in the southern part of the town are probably laid down by the Solent, with the confluence initially to the west and then through time shifting to the east of Bournemouth. This change in confluence location was created by the two rivers migrating laterally away from each other through time, the Stour towards the north and the Solent towards the south (Allen and Gibbard, 1993). The effect of this was to create an interfluve consisting of terrace remnants from both rivers surviving in the Bournemouth area. To the south the Solent terraces have been truncated by the current coastline, so that only the Taddiford Farm and higher gravels survive in significant quantities. To the north, the Stour terraces survive better with most of the higher 
terraces (Milford-on-Sea Gravel and higher) represented. One exception (with only a $0.23 \mathrm{~km}^{2}$ area surviving) is the Old Milton Gravel, which would appear to have been almost entirely reworked by the river into the Taddiford Farm Gravel (Figure 2a). If correct, then the Taddiford Farm Gravel would have a more enhanced handaxe density than would otherwise have been the case. Although it is difficult to measure this effect, it needs to be borne in mind when interpreting the data for changes in human activity and possibly population through time.

\section{Discussion}

Analysis of the lithic record from the Solent basin has highlighted significant problems with the interpretation of the data, but has also explored ways in which some of these difficulties might be overcome. In addition there are several patterns in the data that relate to human behaviour within the area, which has highlighted possible differences with the records from other river basins in Britain.

The main problem of the Solent basin remains the different interpretations of the terrace mapping and how the different stratigraphies in the various tributary areas correlate with each other. Providing firm answers to this problem will only be achieved through new fieldwork and new dating programmes at key sites. What is also clear from the above analysis is the difficulty of using artefacts as a means of dating the different terraces (Westaway et al., 2006). The main issues are the ongoing debates about the first introduction of new technologies, the frequent use of low sample sizes and the lack of scrutiny of the contexts of the artefact record. It is now clear that the very low occurrence of Levallois artefacts in the Solent basin means that they cannot be used reliably to date the terraces.

The frequent absence of contextual detail is a problem for any interpretation of the Solent record, although by more careful selection of sites some of these problems can be overcome. Further problems arise from the biases introduced into the artefact record from collection history and the disproportionate affect of 'super-sites'. However, the paper has explored ways of addressing these problems through a better understanding of the development of quarrying and urban-growth and by examining the data without the 'super-sites'. The paper has also drawn attention to the difficulties of using the artefact records from the Frome, western Solent and possibly the Avon because of the low numbers of artefacts in many of the terraces; they can only be used reliably for presence and absence data. In contrast, the Bournemouth area and the Test Valley seem to have more robust records that can be used with greater confidence to reconstruct human occupation. These records are not without their difficulties, in particular the issue of reworking of artefacts from higher into lower terraces, which has been shown to be a problem in the Bournemouth area. Future modelling may unravel some of these difficulties.

\section{Patterns in the Solent and Thames data}

Despite all these problems, there are some patterns that can be discerned from careful scrutiny of the data. The first evidence of human appearance in the Solent basin is generally two terraces higher than the highest artefact densities. Handaxes probably occur in the Sway Gravel in the Bournemouth area, Terrace 8 of the Avon, the Setley Plain Gravel of the western Solent and Terrace 6 of the Test. Although at present there are no reliable dates for these terraces, potentially they contain evidence of some of the earliest archaeology in Britain. New dating work is needed on these sites. 
Where the peaks in artefact density occur in the different tributary areas is open to more debate and only the Bournemouth area and the Test Valley can be used with any confidence. Despite the problems in these two areas, the analysis still suggests that the largest densities occur in the Setley Plain and Taddiford Farm gravels for the Bournemouth area, and in Terrace 4 gravel for the Test Valley. Overall, peak densities probably occurred between MIS 13 and MIS 10.

Some comparisons can be made with the data presented from the Middle Thames (Ashton and Lewis, 2002). Here it was argued that peak artefact densities occurred in MIS 11 and from then on declined, with no clear evidence for artefacts from late MIS 7 or early MIS 6 until late MIS 4. Although the Solent data is less clear, a similar pattern has been identified up to MIS 8, which lends some support to the data from the Middle Thames.

\section{The human occupation of Britain}

If artefacts can be used as a proxy for population during the early Palaeolithic, then these results pose questions about the controlling factors on human presence in Britain. Both the Thames and Solent regions indicate relatively larger populations during the latter part of the Lower Palaeolithic, c. 500-350 kya. The suggestion that Middle Palaeolithic populations were increasingly adapted to the mammoth steppes of Eurasia, and only reached Britain when this biome expanded to the west (Ashton, 2002; Ashton and Lewis, 2002) cannot unfortunately be tested by the current Solent data, because of the paucity of palaeoenvironmental evidence.

The poor Levallois record from the Solent also makes it difficult to test directly the interpretation that the drop in artefact numbers in the Middle Palaeolithic reflects changes in the use and discard of Levallois technology, rather than population decline (White et al., 2006; Scott, 2006). However, indirect evidence is provided by this lack of Levallois together with the overall MIS 8-7 record from south-west England, in particular the rich handaxe sites at Harnham and Broom. The Solent record stands in stark contrast to the large Levallois assemblages from the Thames Valley, with the exception of Warsash which lies on the eastern side of the Solent Basin (Table 3; Figure 1). If handaxe technology dominated assemblages in south-west Britain during this period then similar discard patterns might be expected to those found in the Lower Palaeolithic. This could suggest that the drop in handaxe densities in the Solent is a genuine reflection of lower populations in the early Middle Palaeolithic. Unfortunately, too little is known about handaxe discard patterns in the early Middle Palaeolithic to support models of population decline in this period at the current time.

An alternative explanation for the decline in artefact numbers and possibly human population lies in the changing palaeogeography of Britain. New evidence suggests that the initial breach of the Weald-Artois anticline to create the Dover Strait occurred towards the end of MIS 12, but that there may have been a significant widening of the Strait towards the end of MIS 6 (Gupta et al., 2007; Gibbard, 2007; Toucanne et al., 2009). Although the initial formation of the Strait would have impeded access to Britain in the Channel region, colonisation from the east may have been easier due to the relatively high floor of the southern North Sea Basin. During MIS 11 the height of the floor must have been close to present-day sea-level as shown by the presence of the 'Rhenish fauna' at Swanscombe, Clacton and Tillingham (Kerney, 1971; Roe, 2001; Ashton et al., 2008). However, the North Sea fills a subsiding basin which reaches depths of $40 \mathrm{~m}$ today (Busschers et al., 2008). Entry to Britain across this area was therefore controlled by the progressive deepening of the basin and by climatically-driven 
lowering of sea-level. As a consequence colonisation became increasingly difficult during temperate episodes, so that by MIS 5e a major drop in sea-level of perhaps 30m would have been required to gain easy access from the east (Ashton et al., in press). These changes in geography provide a clear explanation for the decline in Middle Thames and Solent artefact numbers and arguably human population over time.

The changing palaeogeography of Britain might also explain the differences in the early Middle Palaeolithic artefact assemblages in the Thames and Solent rivers. Easterly routes into Britain, along the Thames or other eastern rivers, were dependant on the geography of the North Sea basin. Routes from the south along the Solent, however, were dependant on the width of the English Channel or in cooler episodes the Channel River. By MIS 8 and 7 a drop in sea-level of about $20 \mathrm{~m}$ would have been needed to re-establish a land connection across the North Sea basin. By contrast, a drop of at least 30m would be required in the Dover Strait and a drop of at least $60 \mathrm{~m}$ in the English Channel to significantly reduce the sea-barriers in these areas. These depths are based on current topography, but due to uplift in the Channel region (estimated at between 30-40m since MIS 11; Lagarde et al., 2003) actually underestimate past depths and the challenges to colonisation across this area. The contrasting geographies therefore might have led to colonisations during different climatic and environmental phases in the two regions. It is also likely that these colonisations emanated from different areas, with routes from the south leading into the Channel River and from there into the Solent, Seine and Somme, whereas eastern routes would have led from the Rhine and Meuse into the eastern rivers of England, such as the Thames.

Evidence for regional differences in early Middle Palaeolithic archaeological signatures is also now being identified on mainland north-west Europe, with Levallois dominated industries in northern France, Belgium and the Netherlands and assemblages with handaxes being found south of the Seine (Scott and Ashton, in press). In combination, this evidence strongly supports the interpretation that the differences in the early Middle Palaeolithic assemblages between the Thames and the Solent is due to colonisation of distinct populations from different regions of north-west Europe. Understanding of the changing palaeogeography of Britain therefore not only provides explanations for the drop in artefact numbers and possible population decline from the Lower into the Middle Palaeolithic, but also provides reasons for changes in technology in different regions through time.

\section{Conclusions}

The Solent Basin contains one of the major resources for understanding the Lower and Middle Palaeolithic of Britain, although there are still problems in the interpretation of the data. Many of these problems can be overcome through careful selection and modelling of that data, together with new fieldwork and dating programmes to understand the chronostratigraphy. Reassessment of the data does, however, broadly support the suggestion of peak populations in Britain during the period MIS 13 to MIS 10, with apparent falls in population from MIS 9. Better understanding of this data should also feed into interpretations of the complex palaeo-geography of Britain and how this might affect different populations entering Britain from different areas of Europe. 


\section{Acknowledgments}

We would like to thank Janet Bell (Salisbury and South Wiltshire Museum, Salisbury), Kay Ainsworth (Hampshire County Museum Service, Winchester), Karen Wardley (Southampton God's House Tower Museum) and Peter Woodward (Dorset County Museum, Dorchester) for providing access to their artefact collections during RH's doctoral research. We are also grateful to Craig Williams for Figures 3-5, Stuart Glenday for help with terrace areas and to Paul Pettitt for providing information regarding material in Portsmouth Museum. Thanks to Wessex Archaeology for kindly permitting use of their CAD data from the Southern Rivers Palaeolithic Project (Wessex Archaeology, 1993) within this paper, and for providing access to the digital data during RH's doctoral research. We would also like to thank Simon Lewis for useful discussions about the text. The research was a contribution to the Leverhulmefunded Ancient Human Occupation of Britain Project.

\section{Bibliography}

Aldhouse-Green SHR. 1995. Pontnewydd Cave, Wales; a later Middle Pleistocene hominid archaeological site: a review of stratigraphy, dating, taphonomy and interpretation. In Human Evolution in Europe and the Atapuerca Evidence, Bermudez de Castro JM, Arsuaga JL and Carbonell E (eds). Junta de Castilla y León; 37-55.

Allen LG. 1991. The evolution of the Solent River system during the Pleistocene. Unpublished PhD thesis, University of Cambridge.

Allen LG, Gibbard PL. 1993. Pleistocene evolution of the Solent River of southern England. Quaternary Science Reviews 12: 503-528.

Allen LG, Gibbard PL, Pettit ME, Preece RC, Robinson JE. 1996. Late Pleistocene interglacial deposits at Pennington Marshes, Lymington, Hampshire, southern England. Proceedings of the Geologists' Association 107: 39-50.

Ashton NM. 1998. The taphonomy of the flint assemblages. In Excavations at the Lower Palaeolithic Site at East Farm, Barnham, Suffolk 1989-94, Ashton NM, Lewis SG, Parfitt SA (eds). British Museum Occasional Paper 125: London; 183-204.

Ashton NM 2002. Absence of humans in Britain during the last interglacial (oxygen isotope stage 5e). In Le Dernier Interglaciaire et les Occupations humaines du Paléolithique Moyen, Roebroeks W, Tuffreau A (eds). CERP: Lille ; 93-103.

Ashton NM, Jacobi RM, White MJ. 2003. The dating of Levallois sites in west London. Quaternary Newsletter 99: 25-32.

Ashton NM, Lewis SG. 2002. Deserted Britain: declining populations in the British Late Middle Pleistocene. Antiquity 76: 388-396.

Ashton NM, Lewis SG, Hosfield RT. in press. Mapping the human record: Population change in Britain during the later Middle Pleistocene. In The Ancient Human Occupation of Britain. Ashton NM, Lewis SG, Stringer CB (eds). Elsevier: Amsterdam.

Ashton NM, Lewis SG, Parfitt SA, Penkman KEH, Coope GR. 2008. New evidence for complex climate change in MIS 11 from Hoxne, UK. Quaternary Science Reviews 27: 652-668.

Ashton NM, Lewis SG, Parfitt SA, White MJ. 2006. Riparian landscapes and human habitat preferences during the Hoxnian (MIS 11) Interglacial. Journal of Quaternary Science 21: 497505.

Barber KE, Brown AG. 1987. Late Pleistocene organic deposits beneath the floodplain of the River Avon at Ibsley, Hampshire. In Wessex and Isle of Wight. Field Guide, Barber KE (ed.). Quaternary Research Association: Cambridge; 62-74.

Briant RM, Bates MR, Boreham S, Cameron NG, Coope GR, Field MH, Keen DH, Simons RMJ, Schwenninger J-L, Wenban-Smith FF, Whittaker JE. 2009a. Gravels and interglacial sediments at Stone Point Site of Special Scientific Interest, Lepe Country Park, Hampshire. In The Quaternary of the Solent Basin and West Sussex Raised Beaches. Field Guide, Briant RM, 
Bates MR, Hosfield RT, Wenban-Smith FF (eds). Quaternary Research Association: London; 171-188.

Briant RM, Bates MR, Hosfield RT, Wenban-Smith FF (eds) 2009b. The Quaternary of the Solent Basin and West Sussex Raised Beaches, Field Guide. Quaternary Research Association: London.

Briant RM, Bates MR, Schwenninger J-L, Wenban-Smith F. 2006. An optically stimulated luminescence dated Middle to Late Pleistocene fluvial sequence from the western Solent Basin, southern England. Journal of Quaternary Science 21: 507-523.

Briant RM, Schwenninger J-L. 2009. Solent river gravels at Badminston Farm, Hampshire SU 463 019. In The Quaternary of the Solent Basin and West Sussex Raised Beaches. Field Guide, Briant RM, Bates MR, Hosfield RT, Wenban-Smith FF (eds). Quaternary Research Association: London; 189-197.

Briant RM, Wenban-Smith FF, Schwenninger J-L. 2009c. Solent river gravels at Barton-on-Sea, Hampshire SZ 230 930. In The Quaternary of the Solent Basin and West Sussex Raised Beaches. Field Guide, Briant RM, Bates MR, Hosfield RT, Wenban-Smith FF (eds). Quaternary Research Association: London; 161-170.

Bridgland DR. 1985. Uniclinal shifting: a speculative reappraisal based on terrace distribution in the London Basin. Quaternary Newsletter 47: 26-33.

Bridgland DR. 1994. The Quaternary of the Thames. Chapman and Hall: London.

Bridgland DR. 2001. The Pleistocene evolution and Palaeolithic occupation of the Solent River. In Palaeolithic Archaeology of the Solent River, Wenban-Smith FF, Hosfield RT (eds) Lithic Studies Society Occasional Paper 7: Southampton; 15-25.

Bridgland DR, Harding P. 1993. Preliminary observations at the Kimbridge Farm quarry, Dunbridge, Hampshire: early results of a watching brief. Quaternary Newsletter 69: 1-9.

Bristow CR, Freshney EC, Penn IE. 1991. Geology of the Country around Bournemouth. Memoir for 1:50,000 Geological Map Sheet 329 (England and Wales). HMSO: London.

Burkitt MC, Paterson TT, Mogridge CJ. 1939. The Lower Palaeolithic industries near Warsash, Hampshire. Proceedings of the Prehistoric Society 5: 39-50.

Bury H. 1923. Some aspects of the Hampshire plateau gravels. Proceedings of the Prehistoric Society of East Anglia 4: 15-41.

Bury H. 1933. The plateau gravels of the Bournemouth area. Proceedings of the Geologists' Association XLIV(3): 314-335.

Busschers FS, van Balen RT, Cohen KM, Kasse C, Weerts HJT, Wallinga, J, Bunnik FPM. 2008. Response of the Rhine-Meuse fluvial system to Saalian ice-sheet dynamics. Boreas 37: 377 398.

Calkin JB, Green JFN. 1949. Palaeoliths and terraces near Bournemouth. Proceedings of the Prehistoric Society 15: 21-37.

Chambers JC. 2005. River gravels and handaxes: new experiments in site formation, stone tool transportation and transformation. In Experimentelle Archäologie in Europa, Bilanz 2004, Heft 3, Fansa M (ed.). Isensee Verlag: Oldenburg; 25-41.

Clarke MR. 1981. The Sand and Gravel Resources of the Country North of Bournemouth, Dorset. Description of Parts of 1:25,000 Sheets SU 00, 10, 20, SZ 0919 and 29. Institute of Geological Sciences Mineral Assessment Report 51. HMSO: London.

Crawford OSG, Ellaway JR, Willis GW. 1922. The antiquity of man in Hampshire. Proceedings of the Hampshire Field Club 9(2): 173-188.

Currant AP. 1986. Man and Quaternary interglacial faunas of Britain. In The Palaeolithic of Britain and its nearest neighbours, Collcutt SN (ed.) University of Sheffield: Sheffield; 50-52.

Currant AP, Jacobi RJ. 2001. A formal mammalian hiostratigraphy for the Late Pleistocene of Britain, Quaternary Science Reviews 20: 1707-16.

Edwards RA, Freshney EC. 1987. Geology of the Country Around Southampton. Memoir for 1:50,000 Geological Map Sheet 315 (England and Wales). HMSO: London.

Gamble CS. 1987. Man the shoveler. Alternative models for Pleistocene colonisation and occupation in northern latitudes. In, The Pleistocene Old World. Regional Perspectives, Soffer O (ed.)

Plenum Press: New York; 81-98. 
Gamble CS. 1992. Comment on Roebroeks W, Conard NJ, van Kolfschoten T. Dense forests, cold steppes and the Paleolithic settlement of northern Europe. Current Anthropology 33: 569-571.

Gibbard, P.L. 1995. The formation of the Strait of Dover. In Island Britain: a Quaternary Perspective, Preece RC (ed.) Geological Society Special Publication 96: London; 15-26.

Gibbard PL. 2007. Palaeogeography: Europe cut adrift. Nature 448: 259-260.

Green HS. 1984. Pontnewydd Cave. A Lower Palaeolithic Hominid site in Wales. National Museum of Wales: Cardiff.

Green JFN. 1946. The terraces of Bournemouth, Hants. Proceedings of the Geologists' Association 57: 82-101.

Green JFN. 1947. Some gravels and gravel-pits in Hampshire and Dorset. Proceedings of the Geologists' Association 58: 128-143.

Gupta S, Collier JS, Palmer-Felgate A, Potter G. 2007. Catastrophic flooding origin of shelf valley systems in the English Channel. Nature 448: 342-345.

Harding P, Gibbard PL, Lewin J, Macklin MG, Moss EH. 1987. The transport and abrasion of flint handaxes in a gravel-bed river. In The Human Uses of Flint and Chert: Proceedings of the Fourth International Flint Symposium, Sieveking G de G, Newcomer MH (eds). Cambridge University Press: Cambridge; 115-126.

Hosfield RT. 1999. The Palaeolithic of the Hampshire Basin. A regional model of hominid behaviour during the Middle Pleistocene. Archaeopress. BAR British series 286: Oxford.

Hosfield RT. 2001. The Lower Palaeolithic of the Solent: 'site' formation and interpretive frameworks. In Palaeolithic Archaeology of the Solent River, Wenban-Smith FF, Hosfield RT (eds) Lithic Studies Society Occasional Paper 7: Southampton; 85-97.

Hosfield RT. 2005. Individuals among palimpsest data. Fluvial landscapes in southern England. In The Hominid Individual in Context, Gamble CB, Porr M (eds) Routledge: London; 220-243.

Hosfield RT, Chambers JC. 2005. River gravels and flakes: new experiments in site formation, stone tool transportation and transformation. In Experimentelle Archäologie in Europa, Bilanz 2004, Heft 3, Fansa M (ed.). Isensee Verlag: Oldenburg; 57-74.

Hosfield RT, Chambers JC. In press. Genuine diversity? The Broom biface assemblage. Proceedings of the Prehistoric Society 75.

Kerney MP. 1971. Interglacial deposits in Barnfield Pit, Swanscombe, and their molluscan fauna. Quarterly Journal of the Geological Society of London 127: 69-93.

Kubala M. 1980. The Sand and Gravel Resources of the Country around Fordingbridge, Hampshire. Description of 1:25,000 Sheet SU 11 and Parts of SU 00, 01, 10, 20 and 21. Institute of Geological Sciences Mineral Assessment Report 50. HMSO: London.

Lagarde JL, Amorese D, Font M, Laville E, Dugué O. 2003. The structural evolution of the English Channel area. Journal of Quaternary Science 18: 201-213.

Marshall GD. 2001. The Broom pits: a review of research and a pilot study of two Acheulian biface assemblages. In Palaeolithic Archaeology of the Solent River, Wenban-Smith FF, Hosfield RT (eds) Lithic Studies Society Occasional Paper 7: Southampton; 77-84.

Mathers SJ. 1982a. The Sand and Gravel Resources of the Country around Lymington and Beaulieu, Hampshire. Description of Parts of 1:25,000 sheets SU 20, 30 and 40 and SZ 29, 39 and 49, Mineral Assessment Report 122: Institute of Geological Sciences.

Mathers SJ. 1982b. The Sand and Gravel Resources of the Country between Dorchester and Wareham, Dorset. Description of Parts of 1:25,000 sheets SY 68, 69, 78, 79, 88, 89, 98 and 99, Mineral Assessment Report 103: Institute of Geological Sciences.

McNabb J. 2007. The British Lower Palaeolithic: Stones in Contention. Routledge: London.

Parfitt SA, Barendregt RW, Breda M, Candy I, Collins MJ, Coope GR, Durbidge P, Field MH, Lee JR, Lister AM, Mutch R, Penkman KEH, Preece RC, Rose J, Stringer CB, Symmons R, Whittaker JE, Wymer JJ, Stuart A J. 2005. The earliest record of human activity in Northern Europe. Nature 438: 1008-1012.

Roberts MB, Parfitt SA. 1999. Boxgrove. A Middle Pleistocene Hominid Site at Eartham Quarry, Boxgrove, West Sussex. English Heritage: London.

Roe DA. 1968. A Gazetteer of British Lower and Middle Palaeolithic Sites. Research Report 8. The Council for British Archaeology: York. 
Roe HM. 2001. The Late Middle Pleistocene biostratigraphy of the Thames Valley, England: new data from eastern Essex. Quaternary Science Reviews 20: 1603-1619.

Roebroeks W, Conard NJ, van Kolfschoten T. 1992. Dense forests, cold steppes and the Paleolithic settlement of northern Europe. Current Anthropology 33: 551-567.

Scott B. 2006. The Early Middle Palaeolithic of Britain; Origins, Technology and Landscape. Unpublished Ph.D. Thesis, University of Durham.

Scott B, Ashton NM. in press. The Early Middle Palaeolithic; the European Context. In The Ancient Human Occupation of Britain. Ashton NM, Lewis SG, Stringer CB (eds). Elsevier: Amsterdam.

Shackley, M.L. 1974. Stream abrasion of flint implements. Nature 248: 501-502.

Smith AJ. 1985. A catastrophic origin for the palaeovalley system of the eastern English Channel. Marine Geology 64: 65-75.

Stapert D. 1976. Some natural surface modification on flint in the Netherlands. Palaeohistoria 18: 841.

Stuart AJ. 1976. The history of the mammal fauna during the Ipswichian/Last Interglacial in England. Philosophical Transactions of the Royal Society of London B276: 221-50.

Toms P, Hosfield RT, Chambers JC, Green CP, Marshall P. 2005. Optical dating of the Broom Palaeolithic sites, Devon \& Dorset. Centre for Archaeology Report 16/2005. English Heritage: London.

Toucanne S, Zaragosi S, Bourillet JF, Cremer M, Eynaud F, Van Vliet-Lanoe B, Penaud A, Fontanier C, Turon JL, Cortijo E and Gibbard PL. 2009. Timing of massive 'Fleuve Manche' discharges over the last $350 \mathrm{kyr}$ : insights into the European ice-sheet oscillations and the European drainage network from MIS 10 to 2. Quaternary Science Reviews

Wenban-Smith FF. 2001. As represented by the Solent River: handaxes from Highfield, Southampton. In Palaeolithic Archaeology of the Solent River, Wenban-Smith FF, Hosfield RT (eds) Lithic Studies Society Occasional Paper 7: Southampton; 57-69.

Wessex Archaeology. 1993. The Southern Rivers Palaeolithic Project Report No. 1. 1991-1992, The Upper Thames Valley, the Kennet Valley and the Solent Drainage System. Wessex Archaeology: Salisbury.

West RG, Sparks BW. 1960. Coastal interglacial deposits of the English Channel. Philosophical Transactions of the Royal Society of London B243: 95-133.

Westaway R, Bridgland DR, White MJ. 2006. The Quaternary uplift history of central southern England: evidence from the terraces of the Solent River system and nearby raised beaches. Quaternary Science Reviews 25: 2212-2250.

White MJ, Ashton NM. 2003. Lower Palaeolithic core technology and the origins of the Levallois method in north-western Europe. Current Anthropology 44: 598-609.

White MJ, Schreve D. 2000. Island Britain - peninsula Britain: palaeogeography, colonisation, and the Lower Palaeolithic settlement of the British Isles. Proceedings of the Prehistoric Society 66: $1-28$.

White MJ, Scott B, Ashton NM. 2006. The Early Middle Palaeolithic in Britain: archaeology, settlement history and human behaviour. Journal of Quaternary Science 21(5): 525-541.

Whittaker K, Beasley M, Bates MR, Wenban-Smith FF. 2004. Harnham. British Archaeology 74: 2227.

Wymer JJ. 1988. Palaeolithic archaeology and the British Quaternary sequence. Quaternary Science Reviews 7: 79-98.

Wymer JJ. 1999. The Lower Occupation of Britain. Trust for Wessex Archaeology and English Heritage: Salisbury. 


\section{Figures and tables}

Figure 1. Map of the Hampshire basin showing the Solent and tributary rivers with underlying geology and the key sites discussed in the text. MP = Moreton Pits; $\mathrm{CM}=$ Corfe Mullen; KP = King's Park; WG = Wood Green; D = Dunbridge; W = Warsash.

Figure 2. Maps of the Solent and tributaries showing distribution of terrace deposits. a. Bournemouth area terrace deposits (Solent River and Stour), after Allen and Gibbard (1993) and Wessex Archaeology (1993). b. Western Solent terrace deposits, after Allen and Gibbard (1993) and Wessex Archaeology (1993). c. Avon Valley terrace deposits, after Kubala (1980) and Wessex Archaeology (1993) d. Test and Itchen Valley terrace deposits, after Edwards and Freshney (1987) and Wessex Archaeology (1993). Figure locations in Solent region indicated in Figure 1. The terrace extent data is derived from the Southern Rivers Palaeolithic Project mapping (Wessex Archaeology, 1993).

Figure 3. Changes in quarrying and urbanisation in the Bournemouth area between 1872 and 1939. a. Terrace area (ha) affected by sand and gravel quarrying; b. Average size of quarries (ha) on each terrace; c. Terrace area (ha) affected by urbanisation.

Figure 4. Handaxe density data for terraces in the Bournemouth area, calculated according to: a. Terrace area; b. Quarried terrace area; c. Urbanised terrace area

Figure 5. Degree of rolling of handaxes for each terrace in the Bournemouth area. Data based on British Museum collections (methodology after Ashton, 1998) and supplemented by data in Hosfield (1999, methodology after Shackley, 1974). Due to differences in recording schemes the Hosfield data was recalibrated by using a test sample from the Corfe Mullen pits.

Table 1. Numbers of handaxes and Levallois artefacts in the terrace gravels of the Solent River and its tributaries. Handaxe density per $\mathrm{km}^{2}$ of terrace area is also given for all rivers, except the River Frome, where there is insufficient data. The following mapping has been used: River Frome - Allen and Gibbard (1993); River Stour - Bristow et al. (1991) and Allen and Gibbard (1993); River Avon Kubala (1980) and Clarke (1981); western Solent - Allen and Gibbard (1993); River Test - Edwards and Freshney (1987). For the Bournemouth area the Pennington Gravel equates with Terraces 1-7 of Bristow et al. (1991).

Table 2. Handaxe densities for terrace units in the Solent and tributaries, shown by percentage. Correlation of the Bournemouth area, western Solent and Avon is based on Kubala (1980) and Allen and Gibbard (1993). OSL dates are from deposits in the western Solent undertaken by Briant et al. (2006). Correlation with the Test terraces is less certain. The correlation suggested here is based on the Stanswood Bay, Tom's Down and Mount Pleasant Gravels being equivalent to those of Test Terraces 4, 3 and 2 respectively (see text). Figures marked 1.6 denote the first reliable occurrence of handaxes within terrace gravels. Figures in bold mark the peaks in handaxe density.

Table 3. Levallois artefacts from the Bournemouth area and the Test valley. Condition of those examined is given. $1=$ fresh; $2=$ slightly rolled; $3=$ rolled; $4=$ very rolled.

Table 4. 'Super-sites' in the Solent catchment showing the nature of the site and the relationship to bedrock. The significance of those sites is given in terms of the percentage of handaxes that each contributes to their terrace and to each area as a whole.

Table 5. Handaxe density data for terraces gravels in the Bournemouth region. a: Urban extents derived from $3^{\text {rd }}$ revision 1:10,560 mapping. b: Quarry extents derived from $1^{\text {st }}$ edition, and $1^{\text {st }}, 2^{\text {nd }}$ and $3^{\text {rd }}$ revisions ('overlapping' quarry extents from different editions/revisions therefore represented sites with extended working lives). 


\begin{tabular}{|c|c|c|c|c|c|c|}
\hline Frome gravels & Handaxes & Levallois & $\begin{array}{r}\text { Terrace } \\
\text { area }\left(\mathbf{k m}^{2}\right)\end{array}$ & $\begin{array}{r}\text { Handaxe } \\
\text { density }\end{array}$ & & \\
\hline Stoborough & 0 & 0 & & & & \\
\hline East Holme & 1 & 0 & & & & \\
\hline Worgret & 3 & 0 & & & & \\
\hline West Knighton & 72 & 0 & & & & \\
\hline Stokeford Heath & 0 & 0 & & & & \\
\hline Higher Hyde Heath & 1 & 0 & & & & \\
\hline Tonerspuddle Heath & 1 & 0 & & & & \\
\hline \multicolumn{7}{|l|}{ Bournemouth area } \\
\hline 'Pennington' & 294 & 0 & 31.9 & 9.2 & & \\
\hline Milford-on-Sea & 83 & 2 & 4.4 & 18.9 & & \\
\hline Stanswood Bay & 32 & 0 & 2.2 & 14.5 & & \\
\hline Taddiford Farm & 853 & 21 & 13.6 & 62.7 & & \\
\hline Old Milton & 55 & 1 & 6.0 & 9.2 & & \\
\hline Setley Plain & 388 & 2 & 5.8 & 66.9 & & \\
\hline Tiptoe & 3 & 0 & 1.7 & 1.8 & & \\
\hline Sway & 12 & 0 & 3.9 & 3.1 & & \\
\hline $\begin{array}{l}\text { Lower Avon } \\
\text { terraces }\end{array}$ & & & & & $\begin{array}{l}\text { Upper } \\
\text { Avon }\end{array}$ & Handaxes \\
\hline T3 & 8 & 0 & 11.9 & 0.7 & Low & 11 \\
\hline T4 & 1 & 0 & 5.1 & 0.2 & & \\
\hline T5 & 3 & 0 & 12.9 & 0.2 & & \\
\hline T6 & 10 & 0 & 4.7 & 2.1 & High & 674 \\
\hline $\mathrm{T} 7$ & 416 & 0 & 8.7 & 47.7 & & \\
\hline T 8 & 8 & 0 & 9.3 & 0.9 & & \\
\hline \multicolumn{7}{|l|}{$\begin{array}{l}\text { Western Solent } \\
\text { terraces }\end{array}$} \\
\hline Pennington & 0 & 0 & 6.0 & 0 & & \\
\hline Lepe & 2 & 0 & 6.4 & 0.3 & & \\
\hline Milford-on-Sea & 8 & 0 & 6.1 & 1.3 & & \\
\hline Stanwood Bay & 16 & 0 & 12.0 & 1.3 & & \\
\hline Taddiford Farm & 0 & 0 & 7.6 & 0 & & \\
\hline Tom's Down & 2 & 0 & 7.8 & 0.3 & & \\
\hline Old Milton & 219 & 2 & 24.8 & 8.8 & & \\
\hline Mount Pleasant & 1 & 0 & 19.3 & 0.1 & & \\
\hline Setley Plain & 5 & 0 & 29.1 & 0.2 & & \\
\hline \multicolumn{7}{|l|}{ Test terraces } \\
\hline $\mathrm{T} 1$ & 32 & 0 & 13.5 & 2.4 & & \\
\hline $\mathrm{T} 2$ & 353 & 1 & 4.3 & 82.8 & & \\
\hline T3 & 215 & 14 & 14.2 & 15.1 & & \\
\hline $\mathrm{T} 4$ & 1577 & 8 & 11.0 & 142.8 & & \\
\hline $\mathrm{T} 5$ & 13 & 0 & 4.2 & 3.1 & & \\
\hline T6 & 152 & 0 & 13.3 & 11.4 & & \\
\hline $\mathrm{T} 7$ & 5 & 0 & 3.2 & 1.6 & & \\
\hline $\mathrm{T} 8$ & 11 & 0 & 2.3 & 4.8 & & \\
\hline T9 & 1 & 0 & 1.3 & 0.8 & & \\
\hline T10 & 1 & 0 & 1.3 & 0.8 & & \\
\hline T11 & 2 & 0 & 0.6 & 3.6 & & \\
\hline
\end{tabular}

Table 1. Numbers of handaxes and Levallois artefacts in the terrace gravels of the Solent River and its tributaries. Handaxe density per $\mathrm{km}^{2}$ of terrace area is also given for all rivers, except the River Frome, where there is insufficient data. The following mapping has been used: River Frome - Allen and Gibbard (1993); River Stour - Bristow et al. (1991) and Allen and Gibbard (1993); River Avon - Kubala (1980) and Clarke (1981); western Solent - Allen and Gibbard (1993); River Test - Edwards and Freshney (1987). For the Bournemouth area the Pennington Gravel equates with Terraces 1-7 of Bristow et al. (1991). 


\begin{tabular}{|c|c|c|c|c|c|c|c|c|}
\hline $\begin{array}{l}\text { B'mouth/western } \\
\text { Solent gravels }\end{array}$ & $\begin{array}{l}\text { B'mouth \% } \\
\text { handaxes }\end{array}$ & $\begin{array}{l}\text { OSL from } \\
\text { (Briant et } \\
\text { al. } 2006\end{array}$ & $\begin{array}{l}\text { Western } \\
\text { Solent \% } \\
\text { handaxe } \\
\text { density }\end{array}$ & $\begin{array}{l}\text { Avon } \\
\text { terraces }\end{array}$ & $\begin{array}{l}\text { Avon \% } \\
\text { handaxe } \\
\text { density }\end{array}$ & & $\begin{array}{l}\text { Test } \\
\text { terraces }\end{array}$ & $\begin{array}{l}\text { Test \% } \\
\text { handaxe } \\
\text { density }\end{array}$ \\
\hline $\begin{array}{l}\text { Pennington } \\
\text { Lepe }\end{array}$ & 5.3 & $\begin{array}{l}\text { MIS 6-3 } \\
\text { MIS 7b-3 }\end{array}$ & $\begin{array}{l}0 \\
2.6\end{array}$ & $\mathrm{~T} 1-\mathrm{T} 4$ & 1.7 & & & \multirow{3}{*}{$\begin{array}{l}0.9 \\
30.8\end{array}$} \\
\hline $\begin{array}{l}\text { Milford-on-Sea } \\
\text { Stanswood Bay }\end{array}$ & $\begin{array}{l}10.8 \\
8.3\end{array}$ & MIS 8 & $\begin{array}{l}10.6 \\
10.9\end{array}$ & T5 & 0.4 & & $\begin{array}{l}\mathrm{T} 1 \\
\mathrm{~T} 2\end{array}$ & \\
\hline Taddiford Farm & 35.8 & & 0 & T6 & 4.1 & \multirow[b]{2}{*}{$?$} & & \\
\hline $\begin{array}{l}\text { Tom's Down } \\
\text { Old Milton } \\
\text { Mount Pleasant } \\
\text { Setley Plain } \\
\text { Tiptoe } \\
\text { Sway }\end{array}$ & \begin{tabular}{l|}
5.2 \\
\\
$\mathbf{3 8 . 2}$ \\
1.0 \\
1.8
\end{tabular} & & $\begin{array}{l}2.1 \\
\mathbf{7 2 . 0} \\
0.4 \\
1.4 \\
0 \\
0\end{array}$ & $\begin{array}{l}\mathrm{T} 7 \\
\mathrm{~T} 8\end{array}$ & $\begin{array}{l}92.1 \\
1.7\end{array}$ & & $\begin{array}{l}\text { T3 } \\
\text { T4 } \\
\text { T5 } \\
\text { T6 } \\
\text { T7 } \\
\text { T8 } \\
\text { T9 } \\
\text { T10 } \\
\text { T11 }\end{array}$ & $\begin{array}{l}5.6 \\
\\
\mathbf{5 3 . 1} \\
1.2 \\
4.2 \\
0.6 \\
1.8 \\
0.3 \\
0.3 \\
1.3\end{array}$ \\
\hline
\end{tabular}

Table 2. Handaxe densities for terrace units in the Solent and tributaries, shown by percentage. Correlation of the Bournemouth area, western Solent and Avon is based on Kubala (1980) and Allen and Gibbard (1993). OSL dates are from deposits in the western Solent undertaken by Briant et al. (2006). Correlation with the Test terraces is less certain. The correlation suggested here is based on the Stanswood Bay, Tom's Down and Mount Pleasant Gravels being equivalent to those of Test Terraces 4, 3 and 2 respectively (see text). Figures marked 1.6 denote the first reliable occurrence of handaxes within terrace gravels. Figures in bold mark the peaks in handaxe density.

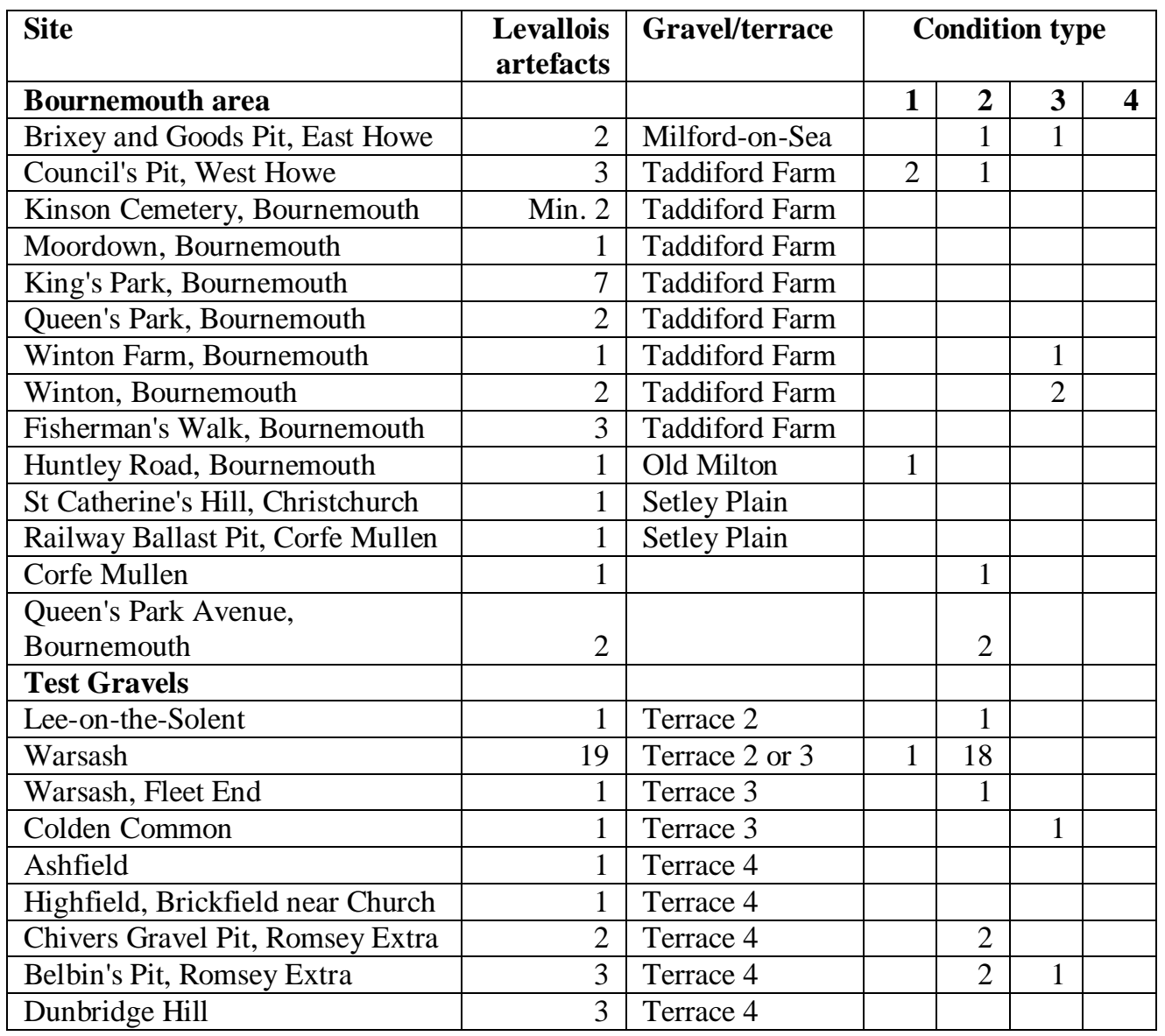

Table 3. Levallois artefacts from the Bournemouth area and the Test valley. Condition of those examined is given. 1 = fresh; 2 = slightly rolled; 3 = rolled; 4 = very rolled. 


\begin{tabular}{|l|l|l|l|l|r|r|r|}
\hline River & Location & Gravel/terrace & Site & Bedrock & Handaxes & $\begin{array}{r}\text { \% terrace } \\
\text { handaxes }\end{array}$ & $\begin{array}{r}\text { \% area } \\
\text { handaxes }\end{array}$ \\
\hline Frome & Moreton & West Knighton & Gravel pits & Chalk/Tertiary & 70 & 97.2 & 90.0 \\
\hline $\begin{array}{l}\text { Western } \\
\text { Solent }\end{array}$ & Barton Cliff & Old Milton & Coastal cliff & Tertiary & 197 & 90.0 & 77.9 \\
\hline Test & Dunbridge & T4 (Test) & Gravel pits & Chalk/Tertiary & 953 & 60.4 & 34.9 \\
\hline B'mouth & Corfe Mullen & Setley Plain & Gravel Pits & Chalk/Tertiary & 289 & 74.5 & 16.8 \\
\hline B'mouth & King's Park & Taddiford Farm & Gravel Pits & Tertiary & 300 & 35.2 & 17.5 \\
\hline Avon & Wood Green & T7 (Avon) & Gravel Pits & Chalk/Tertiary & 409 & 98.3 & 90.1 \\
\hline
\end{tabular}

Table 4. 'Super-sites' in the Solent catchment showing the nature of the site and the relationship to bedrock. The significance of those sites is given in terms of the percentage of handaxes that each contributes to their terrace and to each area as a whole.

\begin{tabular}{|l|r|r|r|r|r|r|r|}
\hline Gravel & $\begin{array}{r}\text { Terrace } \\
\text { Area }\left(\mathbf{k m}^{\mathbf{2}}\right)\end{array}$ & Handaxes & $\begin{array}{r}\text { Density/ } \\
\text { Terrace }\end{array}$ & $\begin{array}{r}\text { Urban Area } \\
\left(\mathbf{k m}^{\mathbf{2}}\right)^{\mathbf{a}}\end{array}$ & $\begin{array}{r}\text { Density/Urban } \\
\text { Terrace }\end{array}$ & $\begin{array}{r}\text { Quarry Area } \\
\left(\mathbf{k m}^{\mathbf{2}}\right)^{\mathbf{b}}\end{array}$ & $\begin{array}{r}\text { Density/ } \\
\mathbf{Q u a r r y}^{-}\end{array}$ \\
\hline & & & & & & & \\
\hline Milford-on-Sea & 4.36 & 83 & 19.0 & 0.35 & 1,029 & 0.02 & 24,147 \\
\hline Stanswood Bay & 2.15 & 32 & 14.9 & 1.30 & 53 & 0.06 & 1,167 \\
\hline Taddiford Farm & 13.59 & 853 & 62.8 & 10.07 & 1,151 & 0.10 & 118,288 \\
\hline Old Milton & 5.99 & 55 & 9.2 & 4.72 & 70 & 0.05 & 6,212 \\
\hline Setley Plain & 5.78 & 388 & 67.2 & 1.90 & 1,180 & 0.09 & 25,189 \\
\hline Tiptoe & 1.72 & 3 & 1.7 & 0.65 & 8 & 0.06 & 86 \\
\hline Sway & 3.90 & 12 & 3.1 & 0.81 & 58 & 0.23 & 207 \\
\hline
\end{tabular}

Table 5. Handaxe density data for terraces gravels in the Bournemouth region. a: Urban extents derived from $3^{\text {rd }}$ revision 1:10,560 mapping. b: Quarry extents derived from $1^{\text {st }}$ edition, and $1^{\text {st }}, 2^{\text {nd }}$ and $3^{\text {rd }}$ revisions ('overlapping' quarry extents from different editions/revisions therefore represent sites with extended working lives). 